\title{
TRENDS IN FATIGUE-CRACK GROWTH FOR THE 2024 Al-ALLOY AFTER A SINGLE TENSILE OVERLOAD
}

\author{
TREND RASTI UTRUJENOSTNE RAZPOKE PRI NATEZNI \\ PREOBREMENITVI Al ZLITINE
}

\author{
Chunguo Zhang ${ }^{1}$, Beibei Lei ${ }^{1}$, Rongwei Liu' ${ }^{1}$, Fengfeng Huo ${ }^{2}$ \\ ${ }^{1}$ Ministry of Education, Chang'an University, Key Laboratory of Road Construction Technology and Equipment, Xi'an 710064, China \\ 2Zhiqi Railway Equipment Co., Ltd, Taiyuan 030032, China \\ zcguo2008@163.com \\ Prejem rokopisa - received: 2018-03-19; sprejem za objavo - accepted for publication: 2018-05-31
}

\author{
doi: $10.17222 /$ mit. 2018.048
}

\begin{abstract}
A single tensile overload (OL) applied during a constant amplitude fatigue test could have a positive or negative influence on improving the subsequent fatigue-crack growth rate $(\mathrm{d} a / \mathrm{d} N)$. The resulting variation in $\mathrm{d} a / \mathrm{d} N$ was very relevant to both the OL level and the fatigue loading conditions. Comprehensive tests on 2024-T4 Al-alloy specimens were carried out to rationalize the variation trend of $\mathrm{d} a / \mathrm{d} N$ after a single tensile OL. It was found that the trend of the fatigue-crack growth after the OL is not unique, but strongly depends on the OL stress-intensity factor $K_{\mathrm{OL}}$ and the applied stress-intensity factor $K_{\text {app }}$ just before OL. Three potential trends of variation in da/dN, related to both the $K_{\mathrm{OL}}$ and the $K_{\mathrm{OL}} / K_{\text {app }}$ ratio, were proposed in this study: initial deceleration and then recovery (Type I); initial slight-acceleration, subsequent retardation and final recovery (Type II); and initial major-acceleration, subsequent retardation and final recovery (Type III). Among the three types, the type II with the medium $K_{\mathrm{OL}} / K_{\text {app }}$ ratio and the low $K_{\text {app }}$ is the optimal OL type for improving the fatigue life of a 2024-T4 Al-alloy specimen.

Keywords: overload, fatigue crack growth trend, fatigue retardation, overload-induced fracture zone
\end{abstract}

Med testom utrujanja s konstantno amplitudo so uporabili posamezen natezni preizkus s preobremenitvijo (OL; angl:: single tensile overload) ter ugotovili, da ima lahko le-ta pozitiven ali negativen vpliv na nadaljnjo hitrost rasti razpoke (da/d $N$ ). Nastala razlika $\mathrm{v} \mathrm{d} a / \mathrm{d} N$ je bila tesno povezana tako z nivojem OL kot tudi s pogoji utrujanja. Avtorji članka so izvedli obširne preizkuse na vzorcih Al zlitine 2024-T4, da bi razumeli trend variiranja da/d $N$ po OL. Ugotovili so, da trend hitrosti rasti razpoke po OL ni enoten, temveč je močno odvisen od razmerja OL-faktor intenzitete napetosti $K_{\mathrm{OL}}$ in uporabljenega nivoja napetostnega faktorja intenzitete $K_{\text {app }}$ tik pred OL. V tej študiji so avtorji predlagali tri možne trende variiranja da/d $N$ glede na $K_{\mathrm{OL}}$ in razmerje $K_{\mathrm{OL}} / K_{\text {app }}$ : začetno zmanjševanje hitrost (zaviranje) in nato popravo (Type $I$ ); začetno rahlo pospeševanje, odlašanje in nato popravo (Type II) in začetno izrazito pospeševanje, kateremu je sledilo odlašanje in končna poprava (Type III). Med vsemi tremi je tip II s srednjim $K_{\mathrm{OL}} / K_{\text {app }}$ razmerjem in nizkim $K_{\text {app }}$ optimalen OL tip za izboljšanje dobe trajanja vzorcev iz Al zlitine 2024-T4.

Ključne besede: preobremenitev, trend rasti utrujenostne razpoke, odlašanje utrujanja, s preobremenitvijo inducirana cona loma

\section{INTRODUCTION}

In recent years the use of Al-alloys has been increasing in the fields of aerospace and automotive due to their excellent performance (e.g., high strength-to-weight ratio and great ductility) and rich reserves. ${ }^{1}$ Because most of the crucial Al-alloy components operate under spectrum loading or variable amplitude cyclic loading where load history influences occur, overload (OL) influences on the subsequent crack-growth behavior have been widely studied from different points of view, ${ }^{2,3}$ e.g., crack-tip blunting, ${ }^{4}$ crack closure ${ }^{5}$ strain hardening, ${ }^{6}$ crack branching, ${ }^{7}$ and compressive residual stress. ${ }^{8}$

The prevailing view on the trend of the variation in $\mathrm{d} a / \mathrm{d} N$ after a single tensile OL during a constant amplitude fatigue test is: initial acceleration, subsequent retardation and final recovery. ${ }^{9,10}$ In order to explore the experimental phenomenon, a deep theoretical and experimental study on the effect of OL on fatigue behavior has been carried out. ${ }^{11-13}$ The authors found that the OL-induced crack closure was the dominant factor in determining the subsequent $\mathrm{d} a / \mathrm{d} N$. A similar conclusion was also reported based on an analysis of the crack-tip displacement fields. ${ }^{14}$ Additionally, the OL-induced plastic zone is also responsible for the variation of the subsequent $\mathrm{d} a / \mathrm{d} N$ because of the reduction in the effective stress-intensity factor $\Delta K_{\text {eff }}{ }^{15,16}$

The loading parameters during constant-amplitude fatigue testing, e.g., the stress ratio, also have a strong influence on the fatigue behavior after OL. ${ }^{17,18}$ That is, a tensile OL has either a positive or a negative influence on the subsequent da/dN. Furthermore, the variation in subsequent $\mathrm{d} a / \mathrm{d} N$ has also been studied by crack kinking, ${ }^{19}$ small secondary cracks, ${ }^{20}$ crack branching, ${ }^{21}$ microstructure, ${ }^{22}$ heterogeneity of the material, ${ }^{23}$ shielding influence, ${ }^{24,25}$ and their combined contributions..$^{26-28}$

By now, a little research has been designed to investigate the potential trends of the resulting variation in $\mathrm{d} a / \mathrm{d} N$ after a single tensile OL. The following questions also need to be considered carefully. (1) There is no interpretation for the initial acceleration of $\mathrm{d} a / \mathrm{d} N$ after OL. (2) The resulting variation in $\mathrm{d} a / \mathrm{d} N$ has not been 
linked to the OL conditions and material properties (e.g., fracture toughness and yield strength). In our previous research, the OL-induced fracture zone at the crack tip was found to be a significant factor in accelerating $\mathrm{d} a / \mathrm{d} N .^{10}$

This study aims at addressing the following key questions:

- Is the trend or pattern of variation in $\mathrm{d} a / \mathrm{d} N$ after a single tensile OL unique?

- Can the variation of $\mathrm{d} a / \mathrm{d} N$ be linked to the OL parameters, e.g., the OL-stress intensity factor $K_{\mathrm{OL}}$ and $K_{\mathrm{OL}} / K_{\text {app }}$ ratio ( $K_{\text {app }}$ is the applied stress-intensity factor)?

- How to elucidate the combined contributions and the dominant influence at each stage (e.g., initial acceleration, subsequent retardation and final recovery stages)?

\section{EXPERIMENTAL PART}

\subsection{Material and specimens}

The material used in this study was 2024-T4 Al-alloy rolled plates with a thickness of $10 \mathrm{~mm}$. The mechanical properties are: tensile strength $\sigma_{\mathrm{UTS}}=445 \mathrm{MPa}$, yield strength $\sigma_{\mathrm{YS}}=301 \mathrm{MPa}$, and elongation $\varepsilon_{\mathrm{r}}=16 \%$. A standard expanded compact-tension (E-CT) specimen geometry with a thickness of $10 \mathrm{~mm}$ was prepared in accordance with the ASTM standards E647 for the measurement of fatigue-crack growth rates $(\mathrm{d} a / \mathrm{d} N)$.

\subsection{Fatigue-crack growth measurement}

Fatigue-crack growth experiments were performed on E-CT specimens under ambient conditions using a servo-hydraulic universal machine with a capacity of 100 $\mathrm{kN}$. Constant-amplitude fatigue loading with a haversine waveform at a frequency of $2 \mathrm{~Hz}$ was used, and the $R$ ratio $=0.05$ and maximum load $P_{\max }=15 \mathrm{kN}$ were set throughout the fatigue test. A fatigue pre-crack of approximately $1 \mathrm{~mm}$ was introduced by gradually increasing the $\Delta K$ in each specimen from the machined U-notch so that the initial crack length after the fatigue pre-cracking is approximately 5.8 from the loading line.

The pre-cracked specimens were divided into four groups and tested under the different OL conditions given below (also summarized in Table 1):

(1) As-received specimen (No OL case): The specimen was tested under the condition of constant-amplitude fatigue loading to final failure without OL, which was taken as a reference to study the OL influence.

(2) The first OL specimen (No. $1 O L$ case): The $1^{\text {st }}$ tensile OL by using $K_{\mathrm{OL}} / K_{\text {app }} \approx 2.14$ was applied when the fatigue crack was $a \approx 7 \mathrm{~mm}$ away from the loading line. The $2^{\text {nd }} \mathrm{OL}$ with $K_{\mathrm{OL}} / K_{\text {app }} \approx 1.81$ was applied at $a \approx$
$12.7 \mathrm{~mm}$. The location of the $2^{\text {nd }} \mathrm{OL}$ was beyond the $1^{\text {st }}$ OL-affected zone because the corresponding da/dN just before the $2^{\text {nd }} \mathrm{OL}$ had not recovered to the normal value.

(3) The second OL specimen (no. 2 OL case): Two OLs with $K_{\mathrm{OL}} / K_{\text {app }} \approx 2.84$ and 1.58 were applied at $a \approx$ $7 \mathrm{~mm}$ and $a \approx 15.2 \mathrm{~mm}$, respectively. For comparison, the location of the $2^{\text {nd }} \mathrm{OL}$ was within the first OL-affected zone.

(4) The third OL specimen (no. 3 OL case): A sole OL with $K_{\mathrm{OL}} / K_{\text {app }} \approx 2.91$ was applied at $a \approx 7.8 \mathrm{~mm}$ to make a comparison with the no. 2 and no. 3 cases.

After the application of the OL, all the specimens were continuously tested under the condition of fatigue cycling.

Table 1: Tensile OL conditions/parameters

\begin{tabular}{|c|c|c|c|c|c|}
\hline \multirow{2}{*}{ Specimen } & OL(s) & $\begin{array}{c}\text { Location } \\
\text { of applied } \\
\text { OL, } \\
a(\mathrm{~mm})\end{array}$ & $\begin{array}{c}K_{\text {app }} \\
(\mathrm{MPa} \sqrt{\mathrm{m}})\end{array}$ & $\begin{array}{c}K_{\mathrm{OL}} \\
\text { just be- } \\
\text { fore OL }\end{array}$ & $K_{\mathrm{OL}} / K_{\text {app }}$ \\
$(\mathrm{MPa} \sqrt{\mathrm{m}})$ & \\
\hline No OL & - & - & - & - & - \\
\hline \multirow{2}{*}{ No.1 OL } & $1^{\text {st }} \mathrm{OL}$ & 7 & 11.3 & 24.22 & 2.14 \\
\cline { 2 - 7 } & $2^{\text {nd }} \mathrm{OL}$ & 12.7 & 18.2 & 33 & 1.81 \\
\hline \multirow{2}{*}{ No.2 OL } & $1^{\text {st }} \mathrm{OL}$ & 7 & 11.3 & 32.79 & 2.84 \\
\cline { 2 - 7 } & $2^{\text {nd }} \mathrm{OL}$ & 15.2 & 24.2 & 38.32 & 1.58 \\
\hline \multirow{2}{*}{ No.3 OL } & $1^{\text {st }} \mathrm{OL}$ & 7.8 & 11.8 & 34.3 & 2.91 \\
\cline { 2 - 7 } & $2^{\text {nd }} \mathrm{OL}$ & - & - & - & - \\
\hline
\end{tabular}

One side of each E-CT specimen was polished to measure the fatigue crack using a USB digital microscope with an accuracy of $0.01 \mathrm{~mm}$. The number of fatigue cycles $(N)$ and the corresponding crack length $a$ were recorded, and thus $\mathrm{d} a / \mathrm{d} N$ could be calculated. The stress-intensity factor range $(\Delta K)$ for the E-CT specimen was calculated with the following equation given by ASTM E647-2015:

$\Delta K=\frac{\Delta P}{B \sqrt{W}} \cdot \frac{\sqrt{\alpha} \cdot(1.4+\alpha)}{(1-\alpha)^{3 / 2}}$.

$\cdot\left(3.97-10.88 \alpha+26.25 \alpha^{2}-28.9 \alpha^{3}+30.15 \alpha^{4}-9.27 \alpha^{5}\right)$

where $\Delta P$ is the applied load range, $B$ is the thickness of sample, $W$ is the width, $\alpha=a /(W-d), a$ is crack length from the loading line, and $0.1 \leq(a+d) / \mathrm{W}<1$.

\subsection{OL-induced crack branching and SEM details of the fracture surface}

To compare the fracture mechanism between the No OL specimen and the OL specimens, the fatigue-fractured surfaces, especially around the OL locations, were observed by scanning electrom microscopy (SEM). Additionally, the polished side of each OL specimen was observed to further study the OL-induced retardation phenomena. 

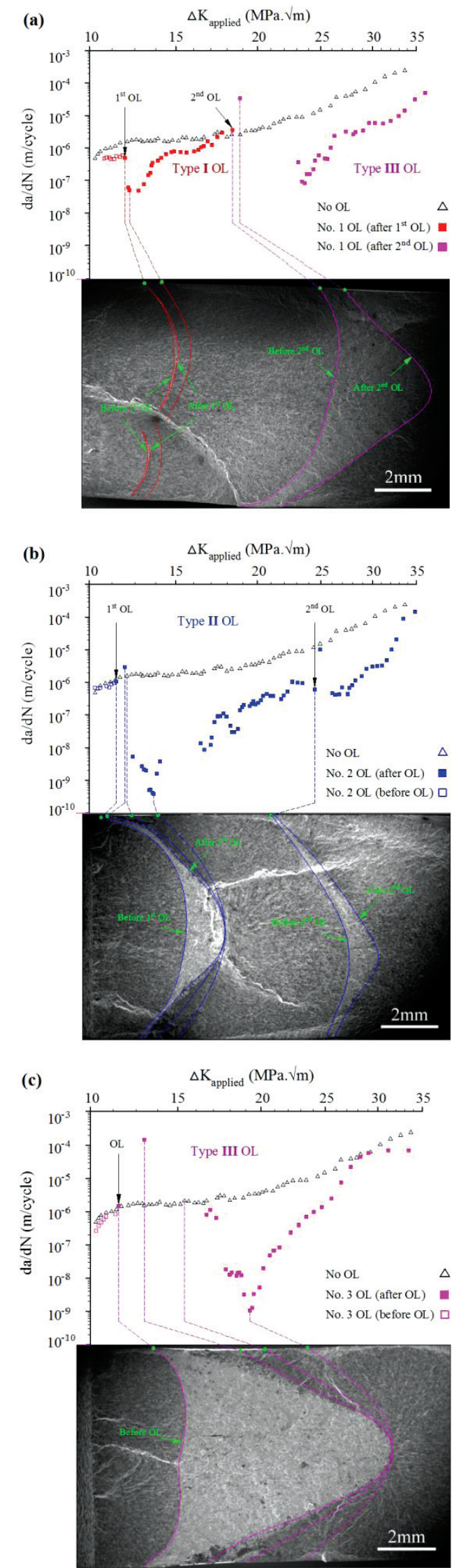

Figure 1: Correlation between the post-OL $\mathrm{d} a / \mathrm{d} N$ and fractured surface for: a) no. $1 \mathrm{OL}, \mathrm{b})$ no. $2 \mathrm{OL}$, and c) no. $3 \mathrm{OL}$

\section{RESULTS}

\subsection{Relation between crack growth rate and fracture surface}

Figure 1 shows the correlation between $\mathrm{d} a / \mathrm{d} N$ as a function of $\Delta K_{\text {app }}$ and the fracture surface, e.g., OL-induced fracture zone (FZ) at the crack tip. It is evident that the trend of the variation in $\mathrm{da} / \mathrm{dN}$ is very different from specimen to specimen, which is closely related to the $K_{\mathrm{OL}} / K_{\text {app }}$ ratio, as listed in Table 1 .

For the $1^{\text {st }} \mathrm{OL}$ in each specimen, the OL-induced FZ begins to occur when the $K_{\mathrm{OL}} / K_{\text {app }}$ ratio is around 2 . However, there is a large FZ for the $2^{\text {nd }} \mathrm{OL}$ with the $K_{\mathrm{OL}} / K_{\text {app }}$ ratio $=1.51$ and 1.81 , respectively. This is because the $K_{\text {app }}$ value just before the $1^{\text {st }}$ OL is much lower than that of the $2^{\text {nd }} \mathrm{OL}$; the latter is closer to the fracture toughness $K_{\text {IC }}$ of the material. Obviously, the magnitude of the OL-induced FZ was closely pertinent to $K_{\text {app }}$ just before OL. ${ }^{10}$ For the $1^{\text {st }}$ and $2^{\text {nd }}$ OLs (corresponding to the lower and higher $K_{\text {app }}$ ), the OL-induced FZ increases with an increase of the $K_{\mathrm{OL}} / K_{\text {app }}$ ratio.

It can be seen from Figure 1 that the FZ almost aligns with the initial acceleration and subsequent retardation stages (O-R region in Figure 2). This is because the FZ had fractured through micro-void coalescence, which is harmful to the fatigue resistance. Interestingly, during the time of the surface crack propagation, the crack tip at the centre of the specimen remained almost immobile. The delay in the crack growth can be attributed to the fact that it needs time to reform the crack front after the OL.

A tensile OL can induce plastic deformation and the resultant compressive residual stress ahead of the crack tip, which can restrain the crack growth. However, a quantitative estimation of the residual stress influences on $\mathrm{d} a / \mathrm{d} N$ is not easy due to the lack of experimental capabilities to measure the stress fields. ${ }^{29}$ In our previous study, an alternative method was proposed by measuring the plastic deformation in the direction of the thickness along the fatigue-crack growth path. ${ }^{10}$ We found that the plastic deformation has a linear decrease with an increase of the distance from the OL point, and covers all the stages (region ' $\mathrm{O}-\mathrm{C}$ ' in Figure 2).

In Figure 1a, the variation in $\mathrm{da} / \mathrm{dN}$ after the $1^{\text {st }} \mathrm{OL}$ consists of two stages: a sharp decrease to the minimum $\mathrm{da} / \mathrm{dN}$ (retardation stage), and a gradual increase to the normal value (recovery stage). But the no. 2 and 3 specimens after the $1^{\text {st }}$ OL show three stages of $\mathrm{d} a / \mathrm{d} N$ variation: initial acceleration, subsequent retardation and final recovery. It should be mentioned that the maximum of $\mathrm{d} a / \mathrm{d} N$ after the $1^{\text {st }} \mathrm{OL}$ in the no. 2 OL specimen is much lower than that in the no. 3 OL specimen. This indicates that the $K_{\mathrm{OL}} / K_{\text {app }}$ ratio influences the magnitude of the plastic deformation and the resultant residual stress, and consequently the subsequent da/dN. A similar conclusion can be obtained for the $2^{\text {nd }} \mathrm{OL}$ in each sample. 

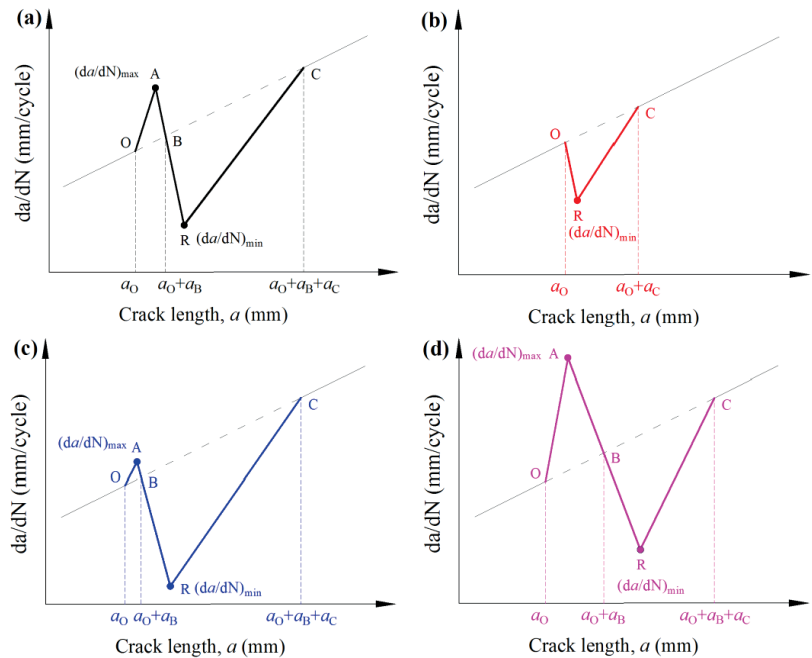

Figure 2: a) The prevailing view on the trend/pattern for the variation in $\mathrm{da} / \mathrm{dN}$ after a single tensile OL, and $\mathrm{b}, \mathrm{c})$ three potential patterns pertinent to the OL condition proposed in this study, $\left(K_{\mathrm{OL}} / K_{\mathrm{app}}\right)_{\mathrm{I}}<$ $\left(K_{\mathrm{OL}} / K_{\mathrm{app}}\right)_{\mathrm{II}}<\left(K_{\mathrm{OL}} / K_{\mathrm{app}}\right)_{\mathrm{II}}$

The prevailing view on the $\mathrm{da} / \mathrm{dN}$ variation after a single tensile OL consists of the three stages, as illustrated in Figure 2a. In fact, the post-OL crack growth behavior strongly depends on the OL parameters, e.g., the $K_{\mathrm{OL}} / K_{\text {app }}$ ratio and the $K_{\text {app }}$ level. Based on the experimental results, we propose three patterns pertinent to the OL condition/parameters, as illustrated in Figure 2b-2d:

Type I: initial deceleration, and then recovery.

Type II: initial slight-acceleration (slight increase in $\mathrm{d} a / \mathrm{d} N)$, subsequent retardation, and final recovery.

Type III (three phases): initial major-acceleration (major increase in $\mathrm{d} a / \mathrm{d} N$ ), subsequent retardation, and final recovery.

For a further quantitative analysis, the parameters and symbols are defined firstly in Figures $\mathbf{2}$ and 3. The OL location is marked as "O". Points "A" and "R" indicate the local maximum $(\mathrm{d} a / \mathrm{d} N)_{\max }$ and minimum $\left.(\mathrm{d} a / \mathrm{d} N)_{\min }\right)$

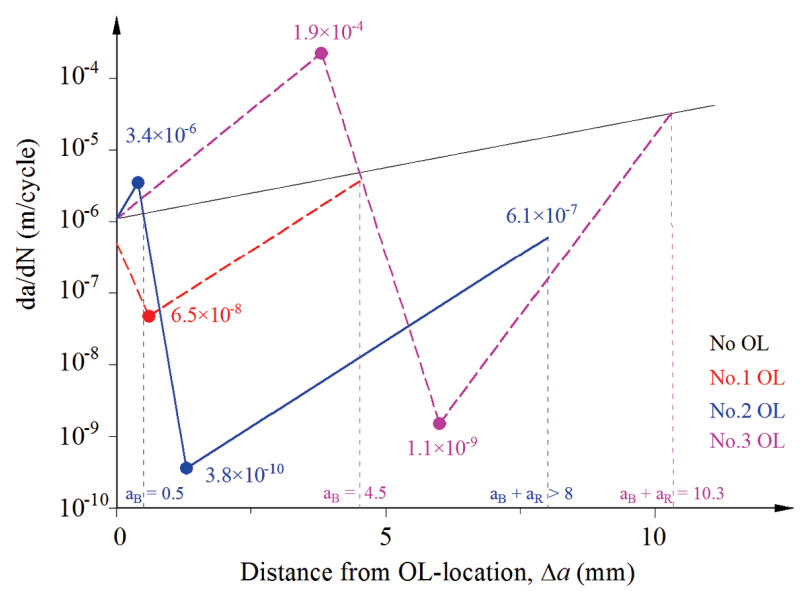

Figure 3: Summary of $\mathrm{d} a / \mathrm{d} N$ vs. $\Delta a$ curves for the three OL(s) specimens after the OL. From A to R, the da/dN value changes from higher than, to equal to ("B" point), to lower than the normal da/dN (marked by dotted line in Figure 2). The critical point corresponding to the normal $\mathrm{da} / \mathrm{dN}$ is defined as the " $\mathrm{C}$ " point. The crack length corresponding to "O", "B" and "C" are $a_{\mathrm{O}}, a_{\mathrm{O}}+a_{\mathrm{B}}$ and $a_{\mathrm{O}}+a_{\mathrm{B}}+a_{\mathrm{C}}$ (in $\mathrm{mm})$, respectively. Figure 3 summaries again the experimental results in Figure 2.

After the $1^{\text {st }}$ OL, no-, slight- and major- acceleration of the $\mathrm{d} a / \mathrm{d} N$ (Figure 1) was observed in the no. 1, 2 and 3 OL specimens, respectively. The corresponding $(\mathrm{d} a / \mathrm{d} N)_{\max }$ is approximately $5.0 \times 10^{-7}, 3.4 \times 10^{-6}$ and 1.9 $\times 10^{-4} \mathrm{~mm} /$ cycle, and the corresponding $(\mathrm{d} a / \mathrm{d} N)_{\min }$ is approximately $6.5 \times 10^{-8}, 3.8 \times 10^{-10}$ and $1.1 \times 10^{-9}$ $\mathrm{mm} /$ cycle, respectively. It is evident that $(\mathrm{d} a / \mathrm{d} N)_{\max }$ increases with an increase of the $K_{\mathrm{OL}} / K_{\text {app }}$ ratio, but $(\mathrm{d} a / \mathrm{d} N)_{\min }$ first decreases then increases. Interestingly, the size of the region O-R-C or B-R-C (prolonging the fatigue life) has a similar tendency: $a_{\mathrm{C}}=4.5 \mathrm{~mm}, a_{\mathrm{C}} \mathfrak{£} 3 / 4$ $7.5 \mathrm{~mm}$ and $a_{\mathrm{C}}=5.8 \mathrm{~mm}$ in the no. 1,2 and $3 \mathrm{OL}$ specimens, respectively. A direct comparison between the $\mathrm{d} a / \mathrm{d} N$ variations after OL additionally found that with an increase of the $K_{\mathrm{OL}} / K_{\text {app }}$ ratio: (i) the OL-affected zone "O-C" and accelerated zone "O-A-B" increase, but the retardant zone "O-R-C or B-R-C" first increases then decreases; (ii) the size ratio of the "retardant-zone" to the "accelerated-zone" reduces monotonously.

The fatigue lives (from $a=4.6 \mathrm{~mm}$ to final failure under the same fatigue loading) of the No OL and three OLed specimens are summarized in Table 2. It is evident that the no. 2 OL specimen (both OLs are Type II) has the longest fatigue life. The fatigue life is approximate 62 times, 15 times and 2.3 times those of the no, no. 1 and no. 3 OL samples, respectively.

Table 2: Fatigue lives of specimens subjected to different OL(s)

\begin{tabular}{|c|c|c|}
\hline Specimen & $\begin{array}{c}\text { Fatigue life } \\
\text { (cycles) }\end{array}$ & $\begin{array}{c}\text { Increase in fatigue } \\
\text { life due to OL(s) }(\%)\end{array}$ \\
\hline No OL & 20190 & - \\
\hline No.1 OL & 83689 & 314.51 \\
\hline No.2 OL & 1259126 & 6136.38 \\
\hline No.3 OL & 542399 & 2586.47 \\
\hline
\end{tabular}

* Fatigue load amplitude for no. 2 OL sample increased from $15 \mathrm{kN}$ to $16.8 \mathrm{kN}$ when the crack propagated to $4.15 \mathrm{~mm}$ because of the crack arrest.

Obviously, the magnitude of the OL retardation was also closely pertinent to $K_{\text {app }}$ just before OL, which should not be too high. ${ }^{5}$ The application of the $2^{\text {nd }} \mathrm{OL}$ is more complex if the applied location is within the $1^{\text {st }}$ OL-affected zone. For example, the $(\mathrm{d} a / \mathrm{d} N)_{\max }$ after the $2^{\text {nd }} \mathrm{OL}$ in the no. 1 OL sample suddenly jumped to a higher value in comparison to the normal level, but to a lower value in the no. 2 OL sample.

It should be mentioned that (i) the maximum of the OL-induced plastic deformation occurred at the OL location, but the $(\mathrm{d} a / \mathrm{d} N)_{\min }$ occurs at a certain distance away from the location in all cases: (ii) there is an initial 
acceleration of da/dN for the types II and III OLs, but an initial deceleration for the type I OL.
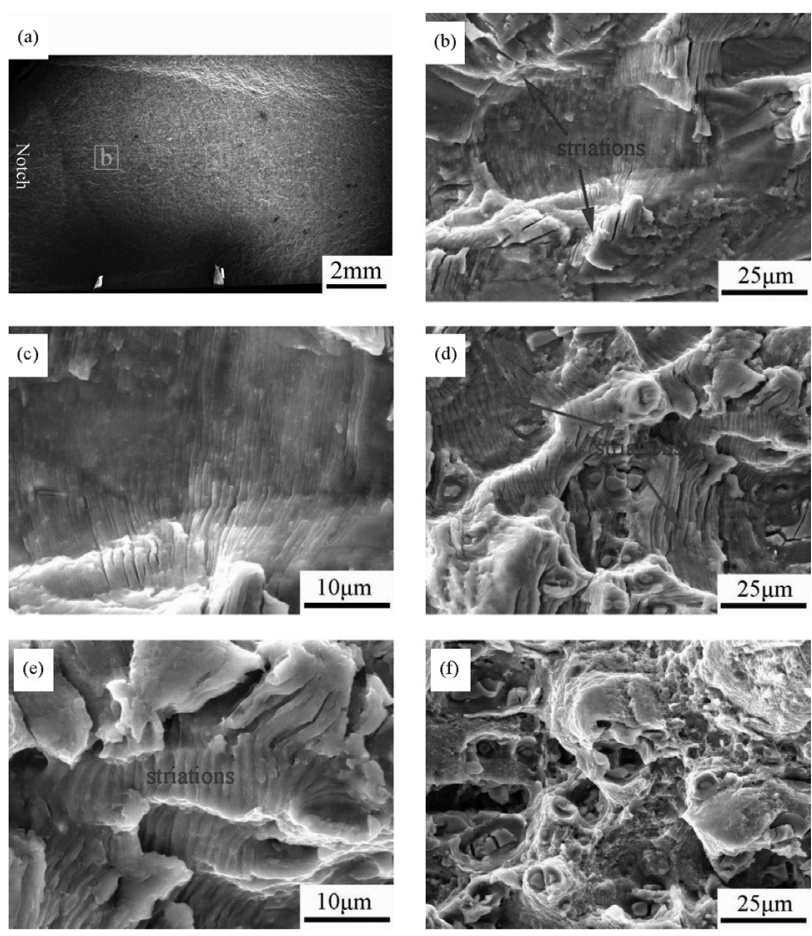

Figure 4: SEM details of the no OL specimen: a) overview, b,c) crack $a=7.8 \mathrm{~mm}$, d,e) $a=11.8 \mathrm{~mm}$, and f) unstable crack propagation
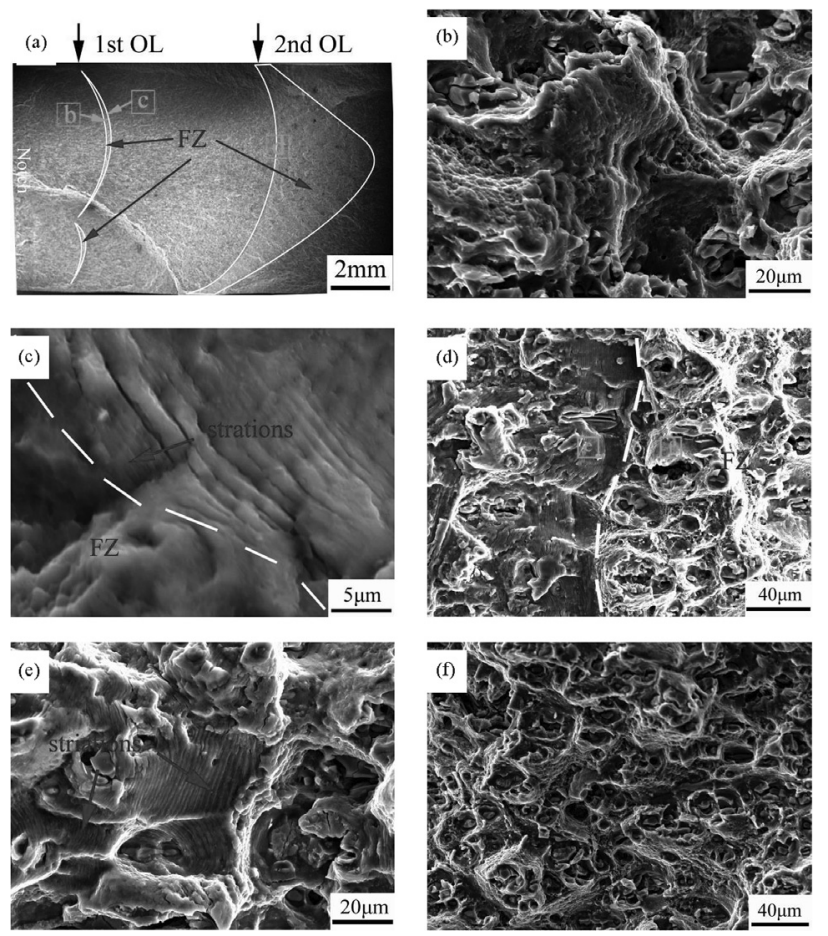

Figure 5: Typical SEM of the no. 1 OL specimen: a) overview showing FZs, b,c) around the $1^{\text {st }}$ OL-induced FZ, d,f) around the front interface of the $2^{\text {nd }} \mathrm{OL}$-induced FZ

\subsection{Fracture-surface characteristics}

The fractured surfaces of the specimens subjected to a constant amplitude fatigue test with and without OL(s) are shown in Figures $\mathbf{4}$ to $\mathbf{7}$, together with overviews indicating their detailed positions.

The effects of a tensile OL on the shape and size of the FZ were discussed using the $K_{\mathrm{OL}} / K_{\text {app }}$ ratio in Section 3.1. By comparison, it can be found that both the size and the crack-tip curved extent of the FZ increase with an increase in the $K_{\mathrm{OL}} / K_{\text {app }}$ ratio for a similar $K_{\text {app }}$ value. An overly high $K_{\mathrm{OL}} / K_{\text {app }}$ ratio or $K_{\mathrm{OL}}$ value can cause unstable crack propagation during the application of the OL due to the effective stress-intensity factor nearly reaching the $K_{\mathrm{IC}}$, e.g., the $2^{\text {nd }} \mathrm{OL}$ in the no. $2 \mathrm{OL}$ specimen and the OL in the no. $3 \mathrm{OL}$ specimen.

For the No OL specimen (Figure 4) the fracture mechanism changed from fatigue striation to micro-void coalescence, and the spacing of the fatigue striations increased gradually with an increase in $\Delta K_{\text {app }}$.

Figures 5 to 7 mainly focus on the OL-affected zones, and the interfaces between the FZ(s) and the fatigue-fractured zones. The fracture mechanism was
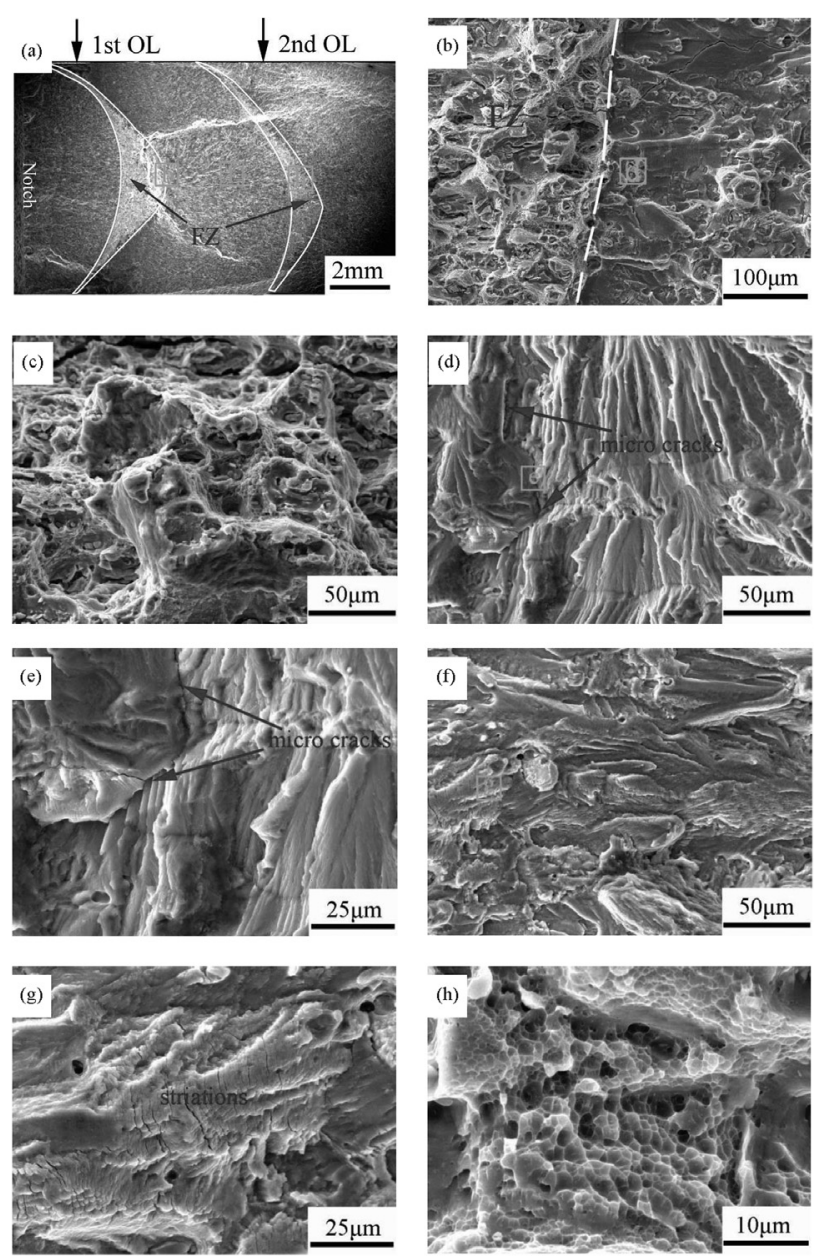

Figure 6: Typical SEM of the no. 2 OL specimen: a) overview, b-e) the back interface after the $1^{\text {st }} \mathrm{OL}, \mathrm{f}, \mathrm{g}$ ) the fatigue-crack growth zone between the two OLs, and $h$ ) within the $2^{\text {nd }} \mathrm{FZ}$. 

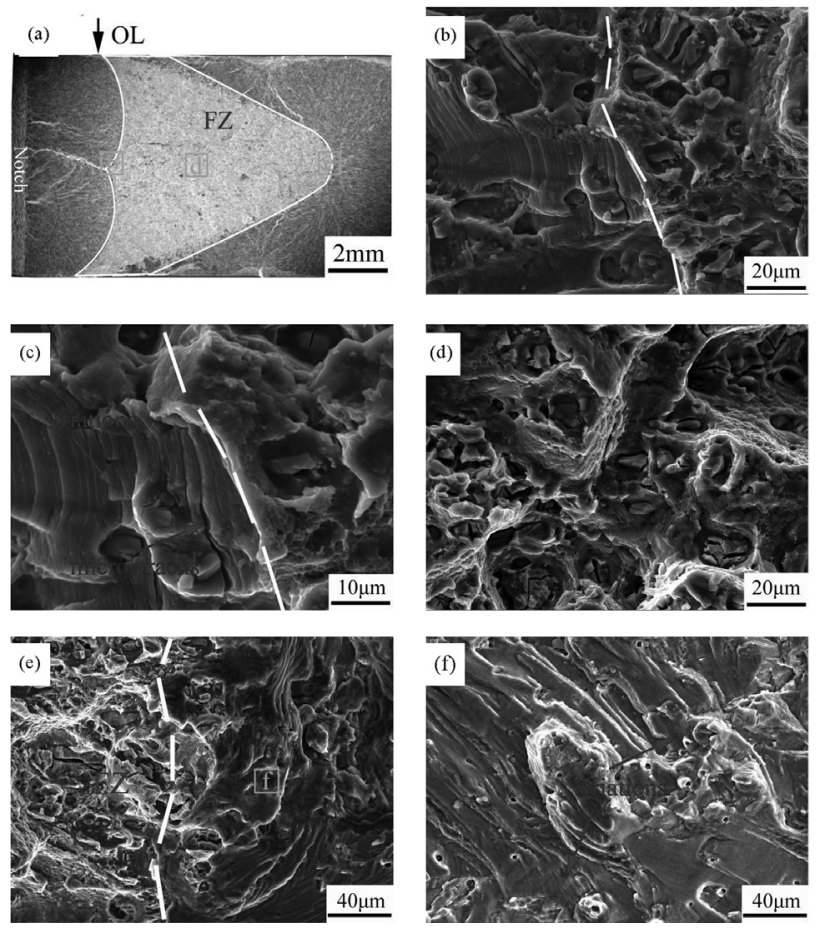

Figure 7: Typical SEM of the no. 3 OL specimen: a) overview, b,c) the front interface between the fatigue growth zone and FZ, d) within the FZ, and e,f) around the back interface

micro-void coalescence within the FZ, which is similar to unstable crack growth, but a mixture of fatigue striation and quasi-cleavage fracture in fatigue-fractured zones. Just after the OL, the proportion of the quasi-cleavage fracture zone increased in the following sequence (Figures 5g, $6 \mathbf{d}$ and $\mathbf{7 f}$ ): the $1^{\text {st }} \mathrm{OL}$ of no. $1 \mathrm{OL}$ specimen (type I), no. 3 OL specimen (type III), and the $1^{\text {st }} \mathrm{OL}$ in no. 2 OL specimen (type II). This proves again that the type-II OL is the best type to prolong the fatigue life of Al-alloys.

Furthermore, the fatigue striations after the FZ become finer in comparison to those just before the OL due to the resultant compressive residual stresses.

\subsection{OL-induced plastic deformation and crack bran- ching}

Figure 8 shows the OL-induced crack branching and plastic deformation near the post-OL crack tip for the no. 2 and 3 OL specimens. For the application of OL at $K_{\text {app }}$ =11-12 MPavm (according $a \approx 7-7.8 \mathrm{~mm}$ ): (i) Crack branching only occurred in the no. 2 OL (type II) and no. 3 OL (type III) specimens, in which the $K_{\mathrm{OL}} / K_{\text {app }}$ ratio was higher than that in the no. 1 specimen (type I); (ii) the distance from the OL location to the post-OL crack tip increases with an increase in the $K_{\mathrm{OL}} / K_{\text {app }}$ ratio; (iii) the branched crack in the no. 2 OL specimen has a length of approximately $300 \mu \mathrm{m}$ with an angle of approximately $45^{\circ}$, but less than $100 \mu \mathrm{m}$ with an angle of $20^{\circ}$ in the no.
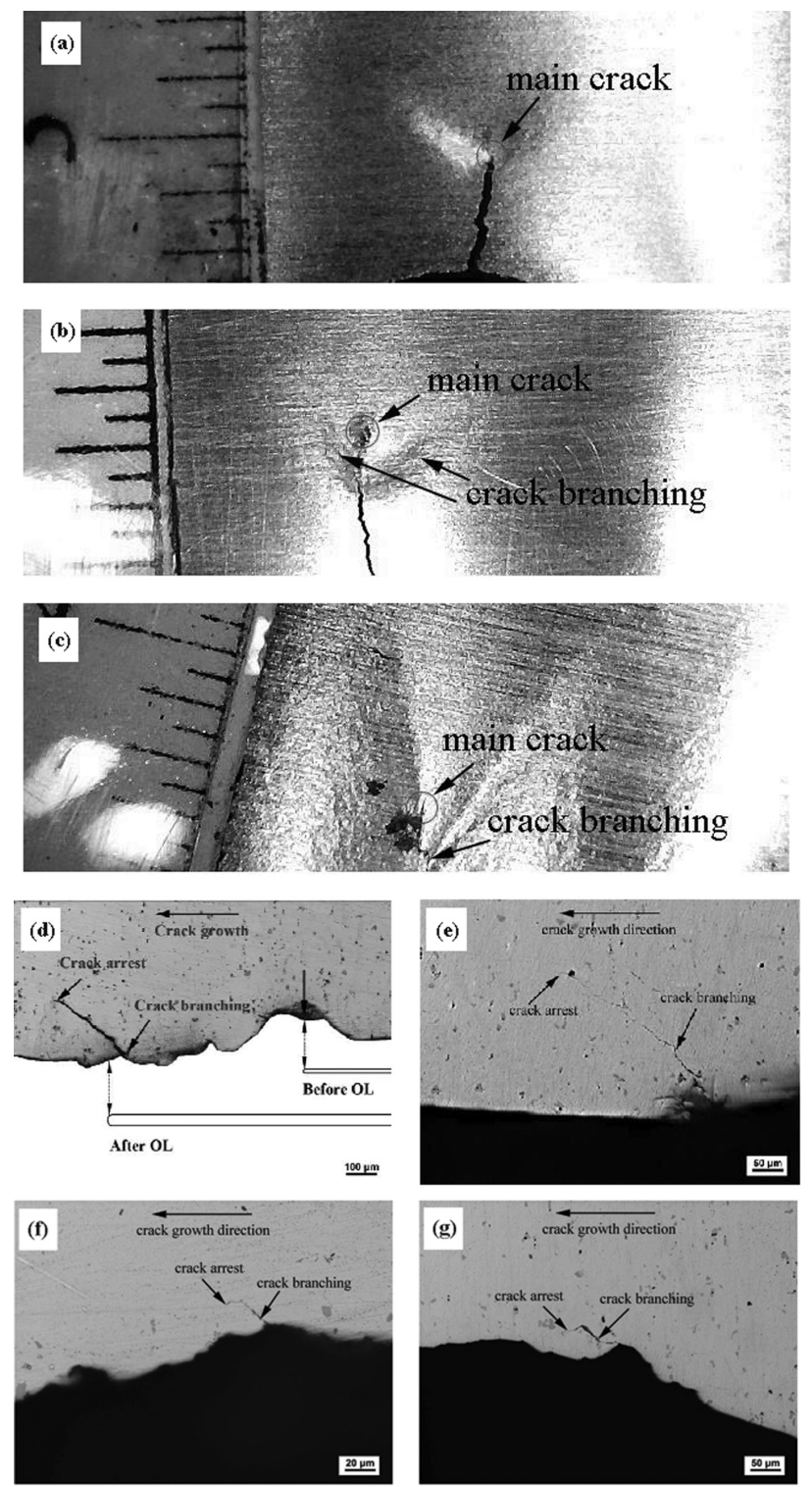

Figure 8: a-c) Macro-plastic deformation around the crack tip in the no. 1 to 3 OL samples, respectively, d,e) micrographs after the $1^{\text {st }}$ and $2^{\text {nd }} \mathrm{OL}$ in the no. 2 OL sample, and $\mathrm{f}, \mathrm{g}$ ) micrographs after OL in the no. 3 OL samples

3 OL specimen. This means the branching crack is also pertinent to the $K_{\mathrm{OL}} / K_{\text {app }}$ ratio and the $K_{\text {app }}$ value.

\section{DISCUSSION}

The application of a single tensile OL during a constant amplitude fatigue test can lead to a deceleration or acceleration in the subsequent $\mathrm{d} a / \mathrm{d} N$ depending on both $K_{\mathrm{OL}}$ and the $K_{\mathrm{OL}} / K_{\text {app }}$ ratio. ${ }^{17}$ The effects of $\mathrm{OL}$ on the variation trend of subsequent $\mathrm{d} a / \mathrm{dN}$ were studied by $\mathrm{d} a / \mathrm{d} N$ vs. $\Delta K$ measurements and detailed SEM observations.

When an OL was applied at a low $K_{\text {app }}$ level (e.g., around $11 \mathrm{MPa} \sqrt{\mathrm{m}}$ for the $2024 \mathrm{Al}$-alloy) or a short crack ( $a \approx 7 \mathrm{~mm}$ in this study), the OL-induced FZ at the 
crack tip began to occur when the $K_{\mathrm{OL}} / K_{\text {app }}$ ratio reached approximately 2.0. Under such a loading condition, type-I OL occurs: the initial deceleration of $\mathrm{d} a / \mathrm{d} N$, and then the recovery. That is, no initial acceleration in $d a / \mathrm{d} N$ was observed. But the degree of subsequent deceleration in $\mathrm{da} / \mathrm{dN}$ was also limited due to the relatively small plastic deformation. ${ }^{10}$ When the $K_{\mathrm{OL}} / K_{\text {app }}$ ratio goes up to around 2.8, type-II OL occurs: initially a slight acceleration of $\mathrm{d} a / \mathrm{d} N$, a subsequent retardation, and a final recovery. Although there is a slight acceleration in $\mathrm{d} a / \mathrm{d} N$ at the beginning, the larger plastic deformation increases the degree of subsequent deceleration in $\mathrm{d} a / \mathrm{d} N$. If the $K_{\mathrm{OL}} / K_{\text {app }}$ ratio further increases to around 3.0, the application of OL led to a decrease in the extent of the reduction in $\mathrm{da} / \mathrm{dN}$ instead, as compared to the type-II OL case.

When the $2^{\text {nd }}$ OL was applied at a high $K_{\text {app }}$ level (e.g., around $20 \mathrm{MPa} \sqrt{\mathrm{m}}$ ) or a long crack, the degree of OL influence reduced because the $K_{\text {app }}$ value was closer to the fracture toughness $K_{\mathrm{IC}}$ in comparison with the corresponding $1^{\text {st }}$ OL.

After the application of a single tensile OL, both the $\mathrm{FZ}$ at the original crack tip and the plastic deformation in front of the post-OL crack tip increase with an increase of the $K_{\mathrm{OL}} / K_{\text {app }}$ ratio and the $K_{\mathrm{OL}}$ level. Here, it should be emphasized that the post-OL crack tip is different to the original one, just before the OL (Figure 8d) if the OL generates a FZ or unstable crack growth during the application of the OL.

The OL-induced plastic deformation increases approximately in linear proportion to the distance away from the location of the applied OL. ${ }^{10}$ That is, the influence degree of factors related to the plastic deformation (e.g., the FZ and the compressive residual stress) decreases with an increase of the distance. The FZ is harmful to the fatigue resistance due to the micro-void coalescence fracture in the area (Figures 5 to 7), but the compressive residual stress is beneficial.

As for the OL-induced FZ, its width in the direction of crack growth is a maximum at the center of the specimen, and decreases along the thickness direction. The $\mathrm{d} a / \mathrm{d} N-\Delta K_{\text {app }}$ curves and the macro-fractured surface in Figure 1 substantiated the delay retardation, which is due to the reformation of the crack front. During the process, the crack tip at the center of the specimen remains almost immobile, and the fatigue-fractured area gradually increased. The most harmful effect of the FZ on increasing the $\mathrm{d} a / \mathrm{d} N$ occurred at the post-OL crack tip, and the degree of influence decreased with an increase in the distance away from the crack tip.

For the type-I OL, the compressive residual stress is the predominant factor governing the subsequent crack growth, and the small FZ has only a little influence. For the types II and III OL, the fatigue crack growth behavior in the first two stages was influenced by both the OL-induced FZ and compressive residual stress. Similar research on compressive residual stresses has been reported in the literature. ${ }^{3,6,10}$ In the first two stages of acceleration and deceleration in $\mathrm{d} a / \mathrm{d} N$, the $\mathrm{FZ}$ was predominant because of the micro-void coalescence fracture. In the recovery stage, the residual stress is the predominant factor.

In the cases of types II and III OL branched cracks emanated near the post-OL crack tip. The length of the branched cracks and their deflection angle to the main crack are pertinent to the $K_{\mathrm{OL}} / K_{\text {app }}$ ratio and $K_{\mathrm{OL}}$ when an OL is applied at low $K_{\text {app. }}$. The branched cracks propagated simultaneously in subsequent fatigue cycling, and thus reduced the driving force for the main crack growth due to the reduction of the stress concentration at the tip of the main crack. The degree of crack-bridging influence on reducing $\mathrm{da} / \mathrm{dN}$ decreases with an increase in the distance from the crack-bridging initiation.

\section{CONCLUSIONS}

The potential or possible variation trends of the subsequent fatigue-crack growth rate $\mathrm{d} a / \mathrm{d} N$ after a single tensile OL in a 2024-T4 Al-alloy specimen were systematically studied, and the main conclusions obtained are summarized as follows:

- The variation trend of $\mathrm{d} a / \mathrm{d} N$ after applying an $\mathrm{OL}$ is closely pertinent to both the $K_{\mathrm{OL}} / K_{\text {app }}$ ratio and $K_{\text {app }}$ just before the OL, and has three potential or possible types: initial deceleration and then recovery (Type I), initial slight-acceleration, subsequent retardation and final recovery (Type II), and initial major-acceleration, subsequent retardation and final recovery (Type III).

- The type-II OL, by applying an OL with a medium $K_{\mathrm{OL}} / K_{\text {app }}$ ratio at low $K_{\text {app }}$, is an optimal OL type for reducing the subsequent $\mathrm{da} / \mathrm{dN}$ in a 2024-T4 Al-alloy specimen.

- Both the size of the OL-induced FZ and the curving degree of the post-OL crack tip curve increase with an increase of the $K_{\mathrm{OL}} / K_{\text {app }}$ ratio for a similar $K_{\text {app }}$ value. An unreasonably high $K_{\mathrm{OL}} / K_{\text {app }}$ ratio or $K_{\mathrm{OL}}$ value can cause unstable crack propagation during the application of OL because the applied stress-intensity factor might be close to or even higher than $K_{\mathrm{IC}}$.

- The initial acceleration of da/dN (types II and III) is because the decrease rate in $\mathrm{da} / \mathrm{dN}$ resulting from the compressive residual stress and crack branching is less than the increase rate from the FZ. The opposite situation was observed for the retardation and recovery stages.

\section{Acknowledgement}

The work was supported by National Nature Science Foundation of China (11672048, 51405029), Shaanxi Province (2017KJXX-11, 2016JQ5020) and Chang'an University (310825153510). 


\section{REFERENCES}

${ }^{1}$ A. Joshi, N. Kumar, K. K. Yogesha, R. Jayaganthan, S. K. Nath, Mechanical properties and microstructural evolution in Al 2014 alloy processed through multidirectional cryoforging, J. Mater. Eng. Perform., 25 (2016) 7, 3031-3045, doi:10.1007/s11665-016-2126-0

${ }^{2}$ L. P. Borrego, J. M. Ferreira, J. M. P. D. Cruz, J. M. Costa, Evaluation of overload effects on fatigue crack growth and closure, Eng. Fract. Mech., 70 (2003), 1379-1397, doi:10.1016/S00137944(02)00119-4

${ }^{3}$ Y. C. Lu, K. X. Li, A new model for fatigue crack growth after a single overload, Eng. Fract. Mech., 46 (1993), 849-856, doi:10.1016/0013-7944(93)90136-G

${ }^{4} \mathrm{~V}$. Tvergaard, Effect of underloads or overloads in fatigue crack growth by crack-tip blunting, Eng. Fract. Mech., 73 (2006), 869-879, doi:10.1016/j.engfracmech.2005.10.009

${ }^{5}$ W. Elber, Fatigue crack closure under cyclic tension, Eng. Fract. Mech., 2 (1970), 37-45, doi:10.1016/0013-7944(70)90028-7

${ }^{6}$ J. F. Knott, A. C. Pickard, Effects of overloads on fatigue-crack propagation: aluminium alloys, Met. Sci., 11 (1977), 399-404, doi:10.1179/msc.1977.11.8-9.399

${ }^{7} \mathrm{~S}$. Suresh, Crack growth retardation due to micro-roughness: A mechanism for overload effects in fatigue, Scripta Metal., 16 (1982), 995-999

${ }^{8}$ W. Sun, S. Huseyin, Residual stress fields during fatigue crack growth, Fatigue Fract. Eng. Mater. Struct., 15 (2007), 115-128, doi:10.1111/j.1460-2695.1992.tb00042.x

${ }^{9}$ S. Y. Lee, P. K. Liaw, H. Choo, R. B. Rogge, A study on fatigue crack growth behavior subjected to a single tensile overload: Part I. An overload-induced transient crack growth micromechanism, Acta Mater., 59 (2011), 485-494, doi:10.1016/j.actamat.2010.09.049

${ }^{10}$ C. G. Zhang, X. Z. Hu, P. M. Lu, G. P. Zhang, Tensile overloadinduced plastic deformation and fatigue behavior in weld-repaired high-strength low-alloy steel, J. Mater. Process. Tech., 213 (2013), 2005-2014, doi:10.1016/j.jmatprotec.2013.05.018

${ }^{11}$ D. Gan, J. Weertman, Fatigue crack closure after overload, Eng. Fract. Mech., 18 (1983), 155-160, doi:10.1016/0013-7944(83) 90104-2

${ }^{12}$ R. D. Brown, J. Weertman, Effects of tensile overloads on crack closure and crack propagation rates in 7050 alumimum, Eng. Fract. Mech., 10 (1978), 867-878, doi:10.1016/0013-7944(78)90040-1

${ }^{13}$ T. S. Gross, J. Weertman, Calorimetric measurement of the plastic vtork of fatigue crack propagation in 4140 steel, Metallurgical Transaction A, 13 (1982), 2165-2172, doi:10.1007/BF02648386

${ }^{14}$ J. M. Vasco-Olmo, F. A. Díaz, Experimental evaluation of the effect of overloads on fatigue crack growth by analyzing crack tip displacement fields, Eng. Fract. Mech., 166 (2016), 82-96, doi:10.1016/ j.engfracmech.2016.08.026

${ }^{15}$ P. Lopez-Crespo, A. Steuwer, T. Buslaps, Y. H. Tai, A. LopezMoreno, J. R. Yates, P. J. Withers, Measuring overload effects during fatigue crack growth in bainitic steel by synchrotron X-ray diffraction, Int. J. Fatigue, 71 (2015), 11-16, doi:10.1016/j.ijfatigue. 2014.03.015
${ }^{16}$ M. A. Wahab, G. R. Rohrsheim, J. H. Park, Experimental study on the influence of overload induced residual stress field on fatigue crack growth in aluminium alloy, J. Mater. Process. Tech., 153 (2004), 945-951, doi:10.1016/j.jmatprotec.2004.04.348

${ }^{17}$ C. Makabe, A. Purnowidodo, A. J. McEvily, Effects of surface deformation and crack closure on fatigue crack propagation after overloading and underloading, Int. J. Fatigue, 26 (2004), 1341-1348, doi:10.1016/j.ijfatigue.2004.03.017

${ }^{18}$ C. Makabe, A. Purnowidodo, T. Miyazaki, A. J. McEvily, Deceleration of acceleration of crack propagation after an overload under negative baseline stress ratio, J. Test. Eval., 33 (2005), 1-7, doi:10.1520/JTE12610

${ }^{19}$ D. G. Pavlou, N. V. Vlachakis, M. G. Pavlou, V. N. Vlachakis, Estimation of fatigue crack growth retardation due to crack branching, Comp. Mater. Sci., 29 (2004), 446-452, doi:10.1016/j.commatsci. 2003.12.003

${ }^{20}$ M. A. Meggiolaro, A. C. O. Miranda, J. T. P. Castro, L. F. Martha, Crack retardation equations for the propagation of branched fatigue cracks, Int. J. Fatigue, 27 (2005), 1398-1407, doi:10.1016/ j.ijfatigue.2005.07.016

${ }^{21}$ T. Zhang, R. Bao, B. J. Fei, Load effects on macroscopic scale fatigue crack growth path in 2324-T39 aluminium alloy thin plates, Int. J. Fatigue, 58 (2014), 193-201, doi:10.1016/j.ijfatigue. 2013.04.014

${ }^{22}$ S. S. Lu, R. Bao, T. Zhang, B. J. Fei, A link-up resulted fatigue crack branching in Al-Cu-Mg alloy, Int. J. Fatigue, 92 (2016), 459-469, doi:10.1016/j.ijfatigue.2016.02.036

${ }^{23}$ S. Daneshour, M. Koçak, S. Langlade, M. Horstmann, Effect of overload on fatigue crack retardation of aerospace Al-alloy laser welds using crack-tip plasticity analysis, Int. J. Fatigue, 31 (2009), 1603-1612, doi:10.1016/j.ijfatigue.2009.04.005

${ }^{24}$ J. M. Vasco-Olmo, F. A. Díaz, Experimental evaluation of plasticity-induced crack shielding from isochromatic data, Opt. Eng., 54 (2015), 081203, doi:10.1117/1.OE.54.8.081203

${ }^{25}$ J. M. Vasco-Olmo, F. A. Díaz, A. García-Collado, R. DoradoVicente, Experimental evaluation of crack shielding during fatigue crack growth using digital image correlation, Fatigue Fract. Eng. Mater. Struct., 38 (2015), 223-237, doi:10.1111/ffe.12136

${ }^{26}$ L. Xiao, D. Y. Ye, C.Y. Chen, J. Z. Liu, L. N. Zhang, Instrumented indentation measurements of residual stresses around a crack tip under single tensile overloads, Int. J. Mech. Sci., 78 (2014), 44-51, doi:10.1016/j.ijmecsci.2013.11.001

${ }^{27}$ E. Salvati, H. J. Zhang, S. F. Kai, X. Song, A. M. Korsunsky, Separating plasticity-induced closure and residual stress contributions to fatigue crack retardation following an overload, J. Mech. Phys. Solids, 98 (2017), 222-235, doi:10.1016/j.jmps.2016.10.001

${ }^{28}$ R. Sunder, A. Biakov, A. Eremin, S. Panin, Synergy of Crack Closure, Near-tip residual stress and crack-tip blunting in crack growth under periodic overloads - A fractographic study, Int. J. Fatigue, 93 (2016), 18-29, doi:10.1016/j.ijfatigue.2016.08.004

${ }^{29}$ S. Daneshpour, J. Dyck, V. Ventzke, N. Huber, Crack retardation mechanism due to overload in base material and laser welds of $\mathrm{Al}$ alloys, Int. J. Fatigue, 42 (2012), 95-103, doi:10.1016/ j.ijfatigue.2011.07.010 